\title{
INFORMACIÓN SOBRE INDICADORES MÉTRICOS DE LA REVISTA DE PSICOPATOLOGÍA Y PSICOLOGÍA CLÍNICA
}

Indicadores de impacto de la revista:

\section{Scopus 2019 (Clinical Psychology)}

CiteScore:

$1.8(\mathrm{Q} 2)$

SJR:

SNIP:

0.757

Indicadores de calidad de la revista:

Categoría ANEP:

Puntuación MIAR (2019):

Opinión Expertos (RESH 2009):
$\mathrm{A}+$

9.9

85.46

Porcentajes de rechazos y artículos que comuniquen resultados de investigación originales (véase la Figura 1).

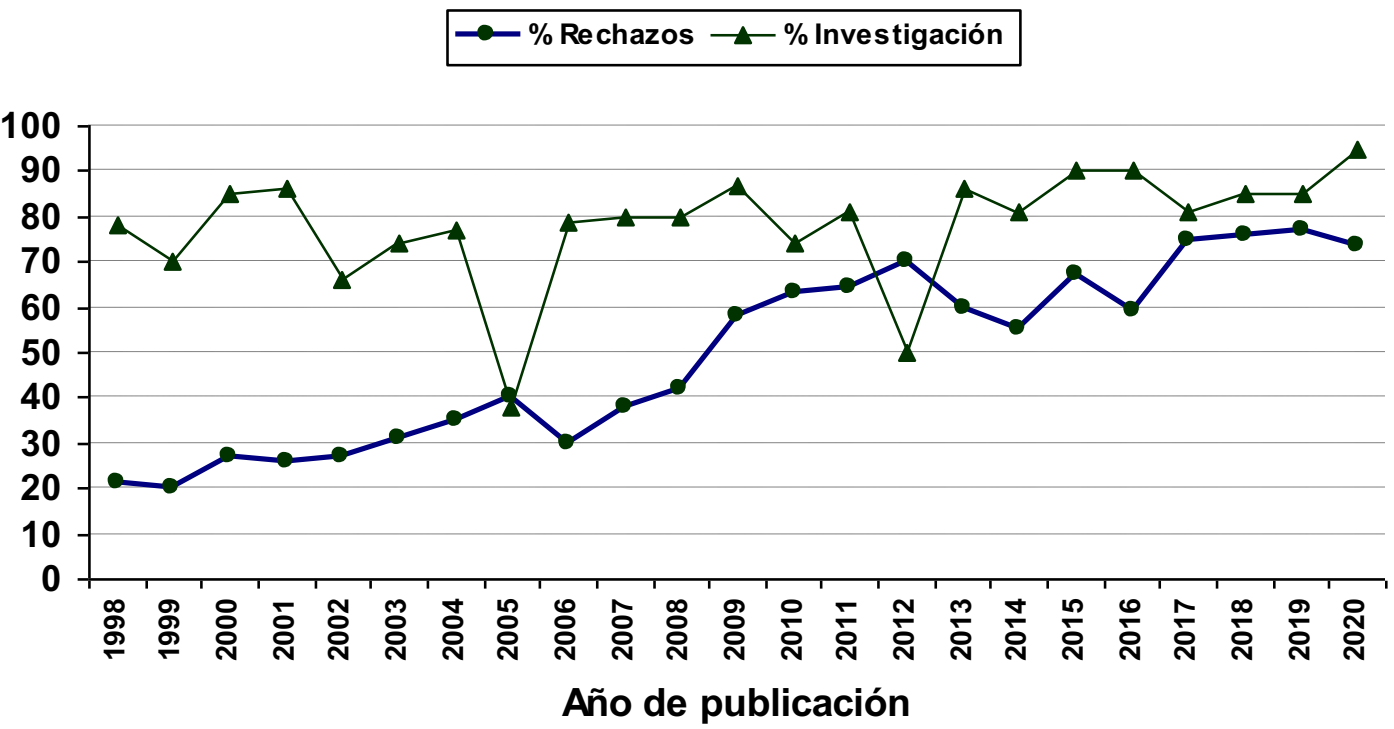

Figura 1. Porcentaje de manuscritos rechazados (rechazos) y artículos de investigación originales (investigación), correspondientes a la Revista de Psicopatología y Psicología Clínica desde 1998 hasta el momento actual. 
